\author{
Abstracta Iranica \\ Abstracta Iranica Revue bibliographique pour le domaine irano-aryen \\ Volume 32-33 | 2013 \\ Comptes rendus des publications de 2009-2010
}

\title{
Ursula Weber, Josef Wiesehöfer. König Narsehs Herrschaftsverständnis
}

\section{Bruno Overlaet}

\section{(2) OpenEdition \\ 1 Journals}

\author{
Electronic version \\ URL: http://journals.openedition.org/abstractairanica/40590 \\ DOI: 10.4000/abstractairanica.40590 \\ ISSN: 1961-960X \\ Publisher: \\ CNRS (UMR 7528 Mondes iraniens et indiens), Éditions de l'IFRI \\ Printed version \\ Date of publication: 1 December 2013 \\ ISSN: 0240-8910

\section{Electronic reference} \\ Bruno Overlaet, « Ursula Weber, Josef Wiesehöfer. König Narsehs Herrschaftsverständnis », Abstracta \\ Iranica [Online], Volume 32-33 | 2013, document 208, Online since 01 July 2016, connection on 02 \\ October 2020. URL : http://journals.openedition.org/abstractairanica/40590 ; DOI : https://doi.org/ \\ 10.4000/abstractairanica.40590
}

This text was automatically generated on 2 October 2020 .

Tous droits réservés 


\title{
Ursula Weber, Josef Wiesehöfer. König Narsehs Herrschaftsverständnis
}

\author{
Bruno Overlaet
}

\section{REFERENCES}

Ursula Weber, Josef Wiesehöfer. « König Narsehs Herrschaftsverständnis », in : H. Börm \& J. Wiesehöfer, eds., Commutatio et Contentio - Studies in the Late Roman, Sasanian, and Early Islamic Near East in Memory of Zeev Rubin. Düsseldorf, 2010, p. 89-132.

1 The authors reconsider the historical context of Narseh's reign, a king often portrayed as an usurper. An analysis of the Paikuli inscription, Shapur's Res Gestae and the royal genealogy serve to prove that Narseh, instead of Wahram, the elder son, stood next in line to the throne when his brother Hormizd I died in $273 \mathrm{AD}$. For twenty years however, he would remain loyal to Wahram I and II and serve as king of Armenia. According to the Paikuli inscription, Narseh was chosen as King of Kings by the assembled Persian nobility after he defeated Wahram III, whose rise to power in 293 AD was not in line with the traditional protocol. The emphasis given to this is evidence that Narseh wanted his reign to be seen not as an usurpation but as a continuation of the royal bloodline. The authors briefly discuss two reliefs of Narseh: the investiture scene at Bishapur (an usurped relief of Wahram I) and the family scene from Naqsh-i Rustam. The latter, erroneously seen by some as an investiture by Anahita, dates back to the end of Narseh's reign. 


\section{AUTHORS}

\section{BRUNO OVERLAET}

Royal Museums of Art and History, Bruxelles 